\section{Lamia Askar Guliyeva Аамія Аскер Кулієва}

$\mathrm{PhD}$ in Philology, Associate Professor of the Department of Diplomacy and Foreign Policy, Baku Slavic University, Azerbaijan

Аоктор філології, Аоцент кафеАри Аипломатії та міжнародної політики, Бакинський слов'янський університет, АзербайАжан

\title{
The Role of UNESCO in Contemporary Global Cultural Processes
}

\author{
Роль ЮНЕСКО \\ в сучасних світових культурних процесах
}

\begin{abstract}
The article examines the role of UNESCO in the modern global cultural processes, with the specific focus on Azerbaijan. The mankind owes awakening of a genuine interest in key global problems of a new rank at the turn of the $20^{\text {th }}-21^{\text {st }}$ centuries primarily to the leading social structures. While the entire civil society of the world today is being challenged, it is gratifying to know that some structures accept and respond to such challenges. In our opinion, UNESCO, being a representative, authoritative, and prestigious organization, is the most striking example of such effective response. The paper examines the permanent public forums in the field of science, culture, and education that are directly supervised by the largest international non-governmental organizations, namely, UNESCO.

Keywords: dialogue of civilizations, public forums, UNESCO, cultural processes, international communities.
\end{abstract}

Problem statement in general and its connection with important scientific or practical tasks. The dialogue of civilizations is an important mean of communication between peoples, one of the radical ways of raising the cultural level, promoting mutual exchange of aesthetic values. The result of a properly established tolerant dialogue of civilizations will invariably increase close and mutually beneficial cooperation on a number of economic, political, and cultural issues. Quite often, acute and urgent problems are brought up on the agenda. The first significant interdisciplinary researches on the topic appeared in academic literature over half a century ago. Some of these studies eventually received political and cultural support from the largest international legal organizations, primarily UNESCO. Urgent problems requiring a decisive and immediate response from high-level representatives of UNESCO generally were included in multilateral projects, programs, resolutions, conferences, etc. Analysis of these issues in the process of the dialogue of civilizations supervised by UNESCO that plays a very important role in contemporary global cultural processes will be the subject of research in this paper.

Literature review. First, it is necessary to define the terminological concept- "dialogue of civilizations". There can never be room in it for the notorious "double standards", lack of agreement or infringement of the rights of one of the parties. The famous Russian politician and culturologist G. Pomerantsev writes, “This kind of dialogue between states and cultures is a conversation in which the spirit of the whole arises and makes its way through the differences of reality. Ideally, in such a dialogue, all interlocutors carefully listen to the truth of the whole, and hegemony belongs to those who are eager to affirm their established opinion on issues of culture and education, and the those who keep the gates of truth open take the lead" [9, p. 61-62].

What Pomerantsev writes about is an open, polemical, tolerant and equal dialogue. Ideally, he should be subordinated to these requirements only. However, it is obvious that such cultural dialogue needs good preliminary preparation. At the present stage, UNESCO has a large role to play in creating appropriate conditions for it. For instance, the Charter of this Organization states, "Only through such a dialogue between cultures, civilizations and peoples will the modern world come to a global awareness of sustainable and systematic further development, which will potentially encompass respect for the legal rights of the individual, including factors of mutual respect and poverty reduction in the world. All this is the essence of the peacekeeping mission and central activity of UNESCO" [11, p. 7].

In addition to the mentioned sources, we also rely on works such as: UNESCO World Report, Meeting of the UNESCO Experts Committee on The Strengthening of UNESCO's Role in Promoting Cultural Diversity in the Context of Globalization, and The Crash of Civilisations and New Remaking of World Order by Samuel P. Huntigton. 
The aim of this research work is to explore the role of UNESCO in modern world cultural processes, with the specific focus on Azerbaijan.

Results and discussion. It should be recalled that UNESCO is not a political organization in the literal sense of the word. Its original goal is different: the history of UNESCO for several decades in a row constitutes a peacekeeping mission aimed at eradicating poverty, protecting the legal and moral rights of the individual. Hence, the corresponding priority goals are overarching: dialogue of civilizations, mass mobilization of scientific knowledge in the development and further improvement of cultural processes. Cultural diversity is aslo promoted by UNESCO, in particular through intercultural dialogue.

In connection with a wide variety of problems at the turn of the $20^{\text {th }}$ and $21^{\text {st }}$ centuries, the main functions of UNESCO include the creation of the most favorable conditions for conducting a dialogue between countries, cultures, civilizations. Respect for national values should be the basis of such dialogues. It is obvious that a fruitful interfaith dialogue in modern society is not a rejection of the difference in religion, culture, mentality, and the perception of spiritual commandments that exists in different states, but, on the contrary, a harmonious acceptance, development and improvement of basic differences. Cultural values should unite people, not separate them. This is the guarantee of the continuation of the positive cultural dialogue of civilizations as an important socio-dynamic component of the foreign policy of states. To the best of its strength, capabilities and authority, UNESCO does its utmost to strengthen the foundations of just such dialogue.

It seems important to emphasize that the dialogue of civilizations at the turn of the $20^{\text {th }}-21^{\text {st }}$ centuries is perceived by the power elites in a broad sense. There are a number of global public forums on the issue. For example, the economic forum "Dialogue West-East: Integration and Development", "Cultural Dialogue of Civilizations", "International Congress of Industrialists and Entrepreneurs" and others.

Since 2002, the "Dialogue of Civilizations" has been held on the Greek island of Rhodes. Public and state leaders are actively involved in its work, including observers and professional consultants from UNESCO. As a result of many years of work, an Information Booklet was issued [8]. A special Bulletin [3] was published under the International Public Forum "Dialogue of Civilizations". This forum is the practical implementation of the Resolution of the UN General Assembly entitled “The Global Agenda for Cultural Dialogues among Civilizations”. The resolution was adopted on November 9, 2001 at the initiative of the President of the Islamic Republic of Iran Mohammad Khatami.

Ernst Kochetov, President of the Public Academy of Sciences of Geoeconomics and Globalistics, a prominent modern political scientist and culturologist, in his voluminous monograph Dialogue states: "The World Public Forum 'Dialogue of Civilizations' is supported by the network structure of UNESCO and other non-governmental organizations, including the Council of Europe, OPEC, OIC,
ISESCO, ALEXO, as well as scientific institutes and a number of individual participants. Directly under the banner of UNESCO, the 'Dialogue of Civilizations' (World Public Forum - 'Dialogue of Civilizations') as a large independent non-governmental non-profit organization, is destined to actualize in the world community the numerous problems of intercultural dialogue. UNESCO pays special attention to the fact that this forum is an important and very effective tool for the interaction of cultures and civilizations with each other. The results achieved in the course of the long-term work of this forum, allow us to hope for further harmonization of relations in the world public arena, and, consequently, the strengthening of stability on Earth" [7, p. 50].

The following example is quite illustrative. "Thanks to the joint efforts of the participants in the dialogue, the first session of the Forum 'Dialogue of Civilizations' (2007) with the active support of UNESCO supporters received a significant response in the international community. Thus, the 'Rhodes Declaration' adopted by the majority of the participants in the official meeting became a truly pivotal event in the formation of an international network of propagandists for conducting a cultural dialogue, thereby laying a solid foundation for further fruitful cooperation of the member states" [15].

Modern legal Internet websites provide quite reliable information that goes beyond the specified meetings or conferences, as the dialogue of civilizations around the world is gaining strength. For example, since the early 2000s, UNESCO has been covering the work of the Saint Petersburg Dialogue in print. This public forum at a high level represents the interests of Russia and Germany. The Saint Petersburg Dialogue of Civilizations was designed to deepen mutual understanding between these countries. It has official status with two organizations (INIDO - In the field of industrial development and UNESCO - In the field of science, culture and education). Its main task is to establish a constructive dialogue between representatives of various spheres of public life in Russia and Germany. Topical public issues are widely discussed at the forum. This allows to create a solid basis for beneficial cooperation, regardless of the current political situation" [17]. The form of the main activity of this international forum is indicative: all participants of the conference, held annually since 2001, are divided into thematic groups. The working group "Education and Science" is directly supervised by UNESCO.

Thus, it may be concluded that the dialogue of civilizations, naturally organized at the highest state level, enters the permanent field of vision of UNESCO. For this organization, in essence, it becomes a key problem. The periodicity of such dialogue contributes to the strengthening of peace between the Member States of UNESCO, which symptomatically increases the general cultural level of peoples. Cultural dialogue is a part of the Organization's strategy, while simultaneously shaping the goals and objectives of the international communities. Success, however, is ensured by the unique sphere of competence of UNESCO, which covers, as written in the Charter, not only culture, education and science (that is, generalizing factors), but also "information and communication" $[11$, p. 2$]$. 
The fact that some opponents of such strategy (in the modern interpretation referred to as "dialogism" in the world of civilizations) accuse the staff working at the Headquarters or the UNESCO Coordination Office of initiating innovations in science, culture and education in schematism cannot be ignored. More precisely, they are accused in automatic activity (easier to say, work for a "tick"). In connection with such statements, Hegel's words may be recalled: "Reflection is a kind of activity that establishes the laws of opposites, moving from one border of the question to another, but is not capable of realizing their close connection and all-pervading unity in the essence of the problems posed" [5, p. 366]. However, it may also be pointed out that UNESCO, by overseeing (or observing) the dialogues, is precisely seeking "all-pervading unity" in pressing problems.

As a result, UNESCO is convinced that there is no alternative to cultural dialogue between civilizations in the $21^{\text {st }}$ century. Only this way a global awareness of the sustainable degree of development that promotes respect for human rights, leads to mutual respect and, accordingly, the level of poverty reduction may be achieved. Official UNESCO website states: "Such a cultural dialogue, undoubtedly, is the main essence of the peacekeeping mission and well-coordinated activities of high representatives from UNESCO. The general strategy and main activities of this Organization are based on rather broad and specific goals and objectives of many international communities. The tangible achievements of UNESCO in this regard are primarily associated with the unique nature of the sphere of those competencies that comprehensively and deeply embrace science, education, culture, as well as communication and information areas" [16].

The dialogue of civilizations, which, as we can see, is gaining power, naturally asserts the significant role of UNESCO in modern global socio-cultural processes. At the present stage of history, the swiftness of political, economic and sociocultural world shifts requires a constant renewal of generally accepted concepts from scholars. One of such concepts, after some time, may smoothly and naturally replace the other. Still, it must be assumed that there are such concepts in the history of world culture, the scale of which allows to speak of them as basic ones even today-it is these concepts on which the exemplary dialogue of civilizations is based.

These works, in our opinion, should primarily include the monographs of S. Huntington, a prominent Western politician and culturologist. His 1996 book The Clash of Civilizations and the New World Order is an important milestone that marked a new view of the role of culture in modern world processes in different states (albeit mainly European ones). The American political scientist saw the essence of the changes taking place in the world-the change in the ideological confrontation undergoing in a number of states. After the aggressive methods during the Cold War, he believes, "in politics, researchers have gone to the other extreme: they have come to preach no less harsh ethnic, cultural and religious contradictions" [13, p. 18]. Many other scientists shared this opinion, namely the French political scientist E. Todd, the Japanese cultural scientist Fukuyama, etc.
Based on the noted concepts and statements of prominent Western and Eastern scientists, UNESCO seeks to determine its own position in world cultural processes. At the $32^{\text {nd }}$ session of the UNESCO Assembly in October 2003, the following was noted: "In fact, today only countries with deep traditions of their own, that is, national culture, isolated from the global world due to economic backwardness, can resist mass culture. Even developed countries with strong cultural traditions (France, Germany, Russia, Japan and some others) are unable to isolate themselves from the massive influence of Western culture from the outside. They simply have more economic and administrative opportunities to support their national culture, to create a favorable competitive environment for it in the conditions of mass globalization" [6, p. 69-70]. In fact, due to the complexity and contradictions, Western cultural expansion today should be assessed taking into account all the factors of its formation. One cannot, of course, completely deny the existence of powerful economic motives in the development of global markets for cultural products, which cannot be ignored by the participants in international exchanges in this area.

That is why, for example, the famous French sociologist M. Godelier drew the attention of UNESCO representatives to the sense of responsibility of those governments that must "vigilantly monitor the impact of Western patterns". This is done in order to "prevent some states from causing significant damage to other countries in the development of culture and national identity by their standards in the areas supervised by UNESCO” [6, p. 71]. This statement by M. Godelier coincided with the UNESCO Program for the Development of Culture, Science and Education in many countries.

To prove this, one more meeting of scientists of different specialties, important in this context, should be mentioned-the one held in November 2000 under the auspices of UNESCO. It explored various aspects of the impact of the theory of globalization on world cultures. UNESCO was represented by an international group of observers and experts, which headed the assessors in order to prevent unnecessary dramatization of global trends in the cultural spheres of a number of states. The group's report also contains the idea that the negative aspects of globalization often stem from the unwillingness or inability of individual governments, as well as the world community as a whole, to regulate this process. At the same time, the positive impact of globalization on world cultures is not questioned. According to the authors of the report, it "promotes new forms of partnership, exchange and cooperation both between individuals and communities, cultures, peoples and civilizations, thereby creating positive opportunities for mutual enrichment of different cultures, at the same time preventing cultural isolation" [1, p. 238].

Objectively speaking, UNESCO should take a neutral (buffer) position in relation to those "scissors" that arose at the turn of the $20^{\text {th }}-21^{\text {st }}$ centuries between the cultural demands of both the West and Europe, including Russia and partly the Eastern world. However, the stake of the leading Western states on the primacy of their culture 
in the entire progressive world is too high for it not to be noticed in the organization. Western civilization is threatened by the so-called "third disappointment" (the expression of W. Zeber) about the failure of hopes for the universalization of its path of cultural development. It is obvious that mass globalization has not led and is unlikely in the near future to lead to the construction of a world based solely on the values of one Western culture, democracy and liberalism. As it was proclaimed from a high rostrum to UNESCO, this organization, of course, participates in discussions on general cultural processes. The World Cultural Report (2000), in particular, noted: "The rise in the modern world of traditional types of cultures is an indicator of the growth of market demand for products of non-European culture against the general background of the continuing satiety of Euro-American culture" [12, p. 44]. In fact, at the Expert Meeting in the UNESCO Committee, the discussion was about the "wrong formula of power" in the United States, which naturally negatively affects the course of cultural development in different countries.

In this regard, the same UNESCO report provides interesting statistics that "there are only about 11 percent of people in the world who identify themselves to one degree or another with the continent; with individual countriesabout 29 percent, and with specific cities or even provinces-57" [12, p. 46]. This is an illustration to the groundlessness of statements about the future era of unification, the formation of a single world culture or a single civilization. In terms of the participation of an international organization in cultural processes, the conclusions of UNESCO (based on the materials of the above-mentioned report) on the spread of mass culture simultaneously with the development of certain traditional types of cultures are seen as more legitimate. Although, as it was noted above about the non-political nature of UNESCO, it is wrong and even unthinkable to completely remove culture from politics. UNESCO documents state: "Cultural tradition has a tremendous impact on the nature and forms of socio-economic and political development. In this positive world process, it is inappropriate to consider the impact of the cultural factor in isolation from state or corporate policy" $[4, \mathrm{p} .66]$.

Most of the member states of UNESCO, including Azerbaijan, adhere to the positions that in the current globalized world, despite the great accumulated potential, there is still a serious danger of all kinds of conflicts on different grounds for the development of national cultures. This is due to the fact that people are objectively involved not only in the world's positive achievements in political, economic and spiritual spheres, but, unfortunately, they are also subject to the replication of mass culture products that negatively impact their thinking. As noted by the member of the Executive Council of UNESCO V.D. Sredin, "such an unenviable state of affairs in the modern globalization world puts the very factors of national identity under real threat, and, moreover, within the boundaries of not only economically weak countries with low-income cultures, but also the cultural diversity of the entire planet in general" [10, p. 9].
UNESCO today is entrusted with the responsible task of responding in a timely manner to the concerns of the world communities in connection with the increasing destabilization in the world. In such an environment, UNESCO primarily advocates for cultural pluralism in its Member States, reinforcing in the planetary mindset of people that cultural, ethnic and religious diversity does not have a reasonable and sufficiently satisfactory alternative in establishing political and economic stability. It is understood that UNESCO does not lose sight of the spiritual and cultural component of sustainable development and cooperation between countries.

At the one of the sessions of the Roman Senate, Caesar legendarily said: "Rome is not afraid of anyone. Everyone knows it is strong. If he is destined to die someday, it is only from internal strife and within his own political small groups". This was said in ancient times, but today the world in many regions is very fragile, and many cultures in general cannot feel safe either. Internal contradictions are indeed sometimes stronger than external ones. At UNESCO, special emphasis is placed on strengthening not regional, but collective efforts, which on an international scale are aimed at preserving and augmenting cultural balance.

The dynamics of political processes in the recent years proves the sadly inexorable fact that sometimes even the smallest differences in culture, language, religion, and traditions have potential for provoking dangerous interethnic explosions with grave consequences. The events in Fergana (Uzbekistan) in June 1989, for example, show to what large military clashes this can lead. An interethnic conflict between Uzbeks and Meskhetian Turks-illustrates that even close, related cultures nevertheless cannot be insured against confrontation these days. The Arab-Israeli, Serbo-Muslim, Muslim-Croatian and Serbo-Croatian conflicts can also serve as a typical example of the development of events according to this scenario. The wars between the tribes in Burundi and Rwanda also are well-publicized. In fact, there were more of them in the $21^{\text {st }}$ century, but the four named political scenarios are generally called catastrophes of a large scale, as there was serious bloodshed.

By the nature of its initial activity, UNESCO is forced to play a certain (direct and indirect) role in these confrontations. This is natural, since socio-political shifts and disagreements cannot exist in isolation from the national, cultural, from mentality-rooted in the difference between cultures. According to UNESCO, "from 1988 to 1992,78 out of 83 conflicts occurred precisely on intercultural, interethnic and interreligious grounds" [14, p. 13]. In the current conditions, national and cultural identity may sometimes be mobilized for destructive goals and forces, one of UNESCO's primary tasks is to "stimulate positive manifestations of pluralism at this level, including through the harmonization of the development of the newest forms of identity" [14, p. 14].

Conclusions. In the contemporary world, even the most monolithic and ethnically and religiously static societies (for instance, Arab and African) are not homogeneous. 
They are not alone: the data cited in the UNESCO report "Our Cultural Diversity" (1996) suggests that in the most of the multinational states of Western Europe and the United States, cultural pluralism is replacing the dominance of the titular nation characteristic of the era of the nation state. In these countries, ethnic diasporas feel more and more free. They enjoy equal legal, social and civil rights with indigenous ethnic groups and actively influence domestic political, economic and cultural processes. At the same time, successfully adapting to Western values, migrants retain elements of their traditional way of life in everyday life, and in some cases, like, for example, immigrants from China, lead a rather closed existence within their diaspora. As a result, over the last decades of the $20^{\text {th }}$ century, the Latin American, African, Arab

\section{References}

1. Brzezinski, Z. (2006). Vybor: mirovoe gospodstvo ili globalnoe liderstvo [The Choice: Global Domination or Global Leadership]. Mezhdunarodnoe obozrenie.

2. Vyistuplenie Generalnogo direktora UNESCO Koitiro Matsuura na otkryitii Vsemirnogo kongressa informatsionnyih agentstv "Informatsionnyie vyizovyi XXI veka" (n. d.). [Report of the UNESCO Director-General Koïchiro Matsuura at the opening of the] https:// ifap.ru/pr/2004/040924a.htm

3. Vestnik (2006). [Bulletin]. No. 1. Eksperimentalnyiy ekzemplyar.

4. Vsemirnyiy Doklad UNESCO (2000). [UNESCO global report] Parizh. 111 s.

5. Hegel, G.W.F. (1976). Filosofiya religii. V dvuh tomah [Philosophy of religion], vol. 1. Myisl.

6. Doklad Komissii po kulture 32-y sessii Generalnoy konferentsii UNESCO (2002) Parizh. Oktyabr 2003, list 2. Dannyie sayta Instituta mezhdunarodnogo obrazovaniya "Open Doors".

7. Kochetov, E. (2011). Dialog [Dialog]. M.: Ekonomika.

8. Materialy Mezhdunarodnogo obschestvennogo foruma "Dialog tsivilizatsiy" (2006). [Materials of the International social forum "Dialog of civilizations"]. (n. p.).

9. Pomerantsev G. (1996). Dialog i molchanie [Dialog and silence]. Chelovek, 3, 60-65.

10. Sredin, V. (2001). Vystuplenie predstavitelya Rossii, chlena Ispolnitelnogo soveta UNESCO V.D. Sredina v hode tematicheskoy diskussii “UNESCO v epohu globalizatsii”. 162-ya sessiya Ispolnitelnogo Soveta UNESCO. Brussels. $16 \mathrm{~s}$.

11. Ustav UNESCO (2002). [UNESCO Charter]. UNESCO.

12. Meeting of the UNESCO Experts Committee on The Strengthening of UNESCO's Role $m$ Promoting Cultural Diversity in the Context of Globalization (21-22 September 2000). UNESCO Publishing. $196 \mathrm{p}$.

13. Huntigton, S. P. (1996). The Crash of Civilisations and New Remaking of World Order. Simon and Schuster.

14. Towards a constructive pluralism. Report (1999, January). UNESCO. $232 \mathrm{p}$.

15. Materialyi zasedaniya kruglogo stola po teme "Chelovecheskiy kapital v strategii natsionalnogo razvitiya” (2007, March 13). http:// viperson.ru/prnt $1 \mathrm{ID}=286354$

16. Communities. Member States. http://portal.unesco.org/en/201.html

17. Tseli i zadachi foruma [Goals and scope of the forum]. https://petersburger-dialog.ru/home/tseli-i-zadachi-foruma.html and Turkish diasporas in the USA, United Kingdom, France, Germany and other Western countries have become an important component of their national culture. They play an increasingly prominent role in shaping national identity. There is, for example, the strongest influence of Arab and African culture on modern musical trends, as well as the style of dress in the mentioned states.

From what is noted in the article, it becomes obvious how diverse at the turn of the $21^{\text {st }}$ century are the activities of UNESCO on the problems of establishing a dialogue between civilizations, to what extent it has to take part in the many-sided cultural processes taking place in different countries. It is not uncommon for an organization to delve into all kinds of social and cultural nuances.

\section{$\Lambda$ ітература}

1. Бжезинский 3. Выбор: мировое господство ими глобальное миАерство. Москва: Международное обозрение, 2006. 344 с.

2. Выступление Генерального директора ЮНЕСКО Коитиро Мацуура на открытии Всемирного конгресса информационных агентств «Информационные вызовы XXI века». URL: https://ifap. ru/pr/2004/040924a.htm (Аата обращения: 05.09.2019).

3. Вестник. 2006. № 1. Экспериментальный экземпмяр.

4. Всемирный АоклаА ЮНЕСКО. Париж: ЮНЕСКО, 2000. 111 с.

5. Гегель Г.В. Ф. Фимософия религии: в 2 т. Москва: Мысль, 1976.

T. $1.532 \mathrm{c}$.

6. АокмаА Комиссии по культуре 32-й сессии Генеральной конференции ЮНЕСКО. Париж, 2003. Аист 2.

7. Кочетов Э.Г. Аиалог. Москва: Экономика, 2011. 733 с.

8. Материалы Международного общественного форума «Аиалог цивилизаций». 2002-2006. Москва, 2006.

9. Померанцев Г. С. Аиалог и молчание // Человек. 1996. № 3. C. 60-65.

10. СреАин В.А. Выступление преАставителя России, чмена Исполнительного совета ЮНЕСКО В.А. СреАина в ходе тематической Аискуссии «ЮНЕСКО в эпоху глобализации». 162-я сессия Исполнительного Совета ЮНЕСКО. Брюссель, 2001. 16 с.

11. Устав ЮНЕСКО. Брюссель: ЮНЕСКО, 2002. 117 с.

12. Meeting of the UNESCO Experts Committee on The Strengthening of UNESCO's Role m Promoting Cultural Diversity in the Context of Globalization. UNESCO Publishing. 2000. 2122 September. $196 \mathrm{p}$.

13. Huntigton S.P. The Crash of Civilisations and New Remaking of World Order. New York: Simon and Schuster, 1996.314 p.

14. Towards a constructive pluralism. Report. UNESCO. January $1999,232 \mathrm{p}$.

15. Материалы заседания круглого стола по теме «Человеческий капитал в стратегии национального развития». 13 марта, 2007 года. URL: http://viperson.ru/prnt+1ID=286354 (Аата обращения: 05.05.2019).

16. Communities. Member States. URL: http://portal.unesco.org/ en/201.html (access date: 08.09.2019).

17. Цели и задачи форума. URL: https://petersburger-dialog.ru/ home/tseli-i-zadachi-foruma.html (Аата обращения: 05.05.2019). 
Кукієва $\Lambda$.А.

\section{Роль ЮНЕСКО в сучасних світових кумьтурних процесах}

Анотація. АосліАжено роль ЮНЕСКО у сучасних світових культурних процесах, з акцентом на АзербайАжан. ПробуАженню інтересу Ао низки нових ключових світових проблемам на межі XX-XXI століть АюАство завАячує провіАним соціальним структурами. Громадянське суспільство в усьому світі зараз постає переА викликами, тож те, що певні структури приймають ці виклики і віАповідають на них, $\epsilon$ втішним. ЮНЕСКО як преАставницька, авторитетна та престижна організація $є$ найяскравішим прикладом такої структури. У статті досліАжено постійні форуми у сферах науки, культури та освіти, які безпосередньо контролюють найбімьші міжнародні неурядові організації, як-от ЮНЕСКО.

Ключові слова: Аіалог цивімізацій, громадські форуми, ЮНЕСКО, культурні процеси, міжнародні спільноти.

Кумиева $\Lambda$.А.

Роль ЮНЕСКО в современных мировых культурных процессах

Аннотация. Исследуется роль ЮНЕСКО в современных культурных процессах, с акцентом на АзербайАжан. Пробуждением интереса к ряду новых ключевых проблем на рубеже XX-XXI веков человечество обязано ведущим социальным структурами. ГражАанское общество во всем мире сейчас столкнулось с определенными вызовами, поэтому то, что определенные структуры принимают эти вызовы и отвечают на них, явцяется отраАным. ЮНЕСКО как преАставительская, авторитетная и престижная организация - наиболее яркий пример такой структуры. В статье изучены регумярно проводимые форумы в сферах науки, культуры и образования, непосредственно контролируемые наибольшими негосуАарственным организациями, например, ЮНЕСКО.

К^ючевые слова: Аиалог цивилизаций, общественные форумы, ЮНЕСКО, культурные процессы, международные сообщества. 